\title{
PHYTOSTEROL CONTENT IN BENGKOANG (Pachyrhizus erosus)
}

\section{KANDUNGAN PHYTOSTEROL DALAM BENGKOANG (Pachyrhizus erosus)}

\author{
Endang Lukitaningsih \\ Pharmacy Faculty, Gadjah Mada University, Jogjakarta \\ lukitaningsih_end@ugm.ac.id
}

\begin{abstract}
Bengkoang has long been used by ancestors as a raw material for cosmetics. In Indonesia, it is usually eaten raw, sometimes with salt, lemon juice and powdered chili. However, scientific evidences that support the use of bengkoang have not been widely published. Phytosterols from the bengkoang root have been isolated and identified based on their NMR spectrum data and mass spectrum. The result of the structure elucidation informed that B-sitosterol and stigmasterol are major components of phytosterol in bengkoang root. Phytosterol content was about $0.02 \%$ of dry weight bengkoang or $2.76 \%$ in petroleum ether extract of bengkoang, with a ratio of B-sitosterol and stigmasterol (65:35). Therefore, bengkoang can be further exploited as a raw material of phytosterol supplement.
\end{abstract}

\section{ABSTRAK}

Bengkoang telah lama digunakan oleh nenek moyang sebagai bahan baku kosmetika. Di Indonesia, bengkoang biasa dimakan secara langsung bersama dengan garam, jus jeruk atau cabe. Namun hingga saat ini bukti ilmiah yang mendukung pemanfaatan bengkoang tersebut belum banyak dipublikasikan. Phytosterol dari umbi bengkoang telah berhasil diisolasi dan diidentifikasi berdasarkan data spektra NMR dan spektra massa. Hasil elusidasi struktur menginformasikan bahwa B-sitosterol dan stigmasterol merupakan komponen utama phytosterol dalam umbi bengkoang. Kandungan phytosterol berkisar 0,02\% per berat kering bengkoang atau 2,76\% dalam ekstrak petroleum eter, dengan perbandingan B-sitosterol dan stigmasterol (65:35). Dengan demikian bengkoang dapat dimanfaatkan lebih lanjut sebagai bahan baku suplemen phytosterol.

\section{INTRODUCTION}

Phytosterol is a class of sterol compounds contained in plants. It is an integral component of the membrane lipid bilayer (Demel and DeKruyff, 1976; Schuleretal., 1991). Phytosterols are different from the cholesterol on their side chain substitution and the position of double bonds intheir cyclic chain. Because they have a double bond in their cyclic group, then either the phytosterol or cholesterol are susceptible to oxidation (Zhang, et al., 2005). Each plant species has its own characteristic distribution of phytosterols. There are three phytosterol constituents are most commonly found, namely beta-sitosterol, campesterol and stigmasterol (Benveniste, 1986; Benveniste, 2004).

Now, phytosterol is not only used as ingredients such as anti-inflammatory drugs (Parra-Delgado et al. 2004; Dicksonetal. 2007), hormones and vitamins (Dewick, 2002), but also as a nutritional supplement (anticholesterol additives) and cosmetics (as a cream and lipsticks) (Berezin et al., 2001). Gomes et al. (2007) reported that betasitosterol and stigmasterol isolated from Plucheaindica Less plant was able to against the snake venom.

In addition, phytosterols are also able to reduce cholesterol absorption, so the prevalence of cardiovascular disease and cancer can be reduced by dietary phytosterol. Sitosterol was reported to inhibit the growth of colon cancer cells HT-29 (Awad, et al., 1996) and LNCaP prostate cancer cells (Holtz, et al., 1998). The effect of sitosterol and campesterol on breast cancer cell apoptosis MDAMB-231 has also been reported by Downie et al. (1999). However, until now the mechanism of inhibition of cell growth and stimulate apoptosis of the sitosterol is not well known (Moon, etal., 2007).

\section{METHODOLOGY \\ Plant materials}

The bengkoang belongs to the taxonomic class of Magnoliopsida; order Fabales; family Fabaceae; subfamily Faboideae; genus Pachyrhizus; species Pachyrhizus erosus. The bengkoang Pachyrhizus erosus (L) Urb roots were collected from Purworejo, Central Java, Indonesia in dry season.

\section{Chemicals and solvents}

The chemicals used in the detection and isolation methods were anisaldehyde (4methoxybenzaldehyde), glacial acetic acid, aluminium chloride, hydrochloric acid and concentrated sulphuric acid (all purchased from Merck, Darmstadt, Germany), Sephadex LH20 (Aldrich, Steinheim, Germany), Silica gel 60 (particle sizes 0.063-0.200mm, Merck, Darmstadt, Germany), TLC Aluminium sheets, 
silica gel 60 F254 (layer thickness $0.2 \mathrm{~mm}$, Merck, Darmstadt, Germany).

Solvents for separation techniques were petroleum ether, ethyl acetate (Fisher Scientific, Leichestershire, UK), methanol (Merck, Darmstadt, Germany), chloroform, dichloromethane, from the Fluka, Seelze, Germany.

\section{Instruments}

Melting point SMP3 Stuart ${ }^{\circledR}$ apparatus (Staffordshire, UK), Cary 50 Bio UV-Visible spectrophotometer (Varian, California, USA), JASCO FT/IR-6100 Spectrophotometer (GrossUmstadt, Germany), ALPHA II-12 Freeze dryer (Osterode, Germany), Bruker Avance 400 NMR spectrometer (Rheinstetten, Germany), Shimadzu GC/MS-QP 20105 gas chromatography (Kyoto, Japan).

\section{Extraction and isolation of phytosterol from bengkoang}

The bengkoang roots $(45 \mathrm{~kg})$ were peeled and washed with water, subsequently dried at $60^{\circ} \mathrm{C}$ and milled into fine powder. The fine powder $(4.75 \mathrm{~kg})$ was extracted by soxhlet using petroleum ether.

The petroleum ether extract (26.3 gram) was further subjected to silica gel chromatography and eluted using gradient mixture of PE-EtOAc (from 100\% of PE to $100 \%$ of EtOAc) and followed by gradient mixture of EtOAc-MeOH (from $100 \%$ of EtOAc to $100 \%$ of $\mathrm{MeOH}$ ). 29 fractions of $100 \mathrm{ml}$ were collected according to the TLC results. TLC was conducted to each fraction respectively using silica gel as a stationary phase, chloroformethyl acetate (6:4) as a mobile phase. Detection was performed with UV light at 254 and $366 \mathrm{~nm}$ and followed by spraying the TLC plates with anisaldehyde $-\mathrm{H}_{2} \mathrm{SO}_{4}$ reagent and subsequent heating at $110^{\circ} \mathrm{C}$. Phytosterol will react positive with anisaldehide and give blue-purple colour.

Fractions 8, 9, 10, 11 have the same spot on TLC with an Rf value of 0.48 . Therefore, they were combined and then subjected to another silica gel column chromatography using dichloromethane-ethyl acetate $(60: 40)$ as a mobile phase. Ten millilitre fractions were collected and evaluated by TLC using dichloromethane-ethyl acetate $(60: 40)$ as mobile phase. Fractions $9-16$ have the same retention factor $(\mathrm{Rf}=0.43)$ on TLC. They were combined and evaporated. The obtained solid was washed with methanol and recrystallized from petroleum ether and ethyl acetate to get pure compound $(727 \mathrm{mg})$. The compound was further analysed by NMR spectrophotometer and gas chromatography equipped by mass spectrophotometer.

\section{RESULT AND DISCUSSION Structure elucidation of isolated phytosterol compound}

\section{Compound P-1 (Stigmasterol)}

White needle crystals; m.p. $136-139{ }^{\circ} \mathrm{C}$; MW 412; IR $\left(\mathrm{cm}^{-1}\right)$ : 3364, 2925, 2834, 1463, 1375, 1051, 1022, 957, 801. EIMS m/z (\% intensity): $412\left(\left[\mathrm{M}^{+\cdot}\right], 30.72\right), 394\left(\left[\mathrm{M}-\mathrm{H}_{2} \mathrm{O}\right]^{+\cdot}, 5.48\right), 379$ $\left(\left[\mathrm{M}-\mathrm{H}_{2} \mathrm{O}-\mathrm{CH}_{3}\right]^{+\cdot}, 5.70\right), 351$ (17.77), 273 (10.94), 271 (26.90), 255 (30.94), 213 (16.51), 159 (35.91), 133 (40.83), 123 (22.21), 105 (15.01), 97 (33.98), 83 (70.32), 69 (55.71), 55 (100), 41 (47.21). ${ }^{1} \mathrm{H}$ NMR (500 MHz, $\mathrm{CDCl}_{3}$ ): $\delta 0.68$ (s, $\left.3 \mathrm{H}, 3 \mathrm{H}^{18}\right), 0.83\left(\mathrm{~d}, 9 \mathrm{H}, 3 \mathrm{H}^{26}, 3 \mathrm{H}^{28}, 3 \mathrm{H}^{29}\right), 0.92$ $\left(\mathrm{s}, 3 \mathrm{H}, 3 \mathrm{H}^{21}\right), 0.95\left(\mathrm{~m}, 1 \mathrm{H}, \mathrm{H}^{9}\right), 1.01(\mathrm{~s}, 3 \mathrm{H}$, $\left.3 \mathrm{H}^{18}\right), 1.09\left(\mathrm{~m}, 1 \mathrm{H}, \mathrm{H}^{15 \mathrm{a}}\right), 1.10\left(\mathrm{~m}, 1 \mathrm{H}, \mathrm{H}^{14}\right)$, $1.20\left(\mathrm{~m}, 3 \mathrm{H}, 2 \mathrm{H}^{25}, \mathrm{H}^{17}\right), 1.28\left(\mathrm{~m}, 1 \mathrm{H}, \mathrm{H}^{20}\right), 1.30$ $\left(\mathrm{m}, 1 \mathrm{H}, \mathrm{H}^{1 \mathrm{~b}}\right), 1.50\left(\mathrm{~m}, 6 \mathrm{H}, 2 \mathrm{H}^{2}, 2 \mathrm{H}^{11}, 2 \mathrm{H}^{24}\right), 1.70$ $\left(\mathrm{m}, 6 \mathrm{H}, \mathrm{H}^{16}, \mathrm{H}^{15 \mathrm{~b}}, \mathrm{H}^{8}\right), 1.84\left(\mathrm{~m}, 1 \mathrm{H}, \mathrm{H}^{1 \mathrm{a}}\right), 1.98$ $\left(\mathrm{m}, 2 \mathrm{H}, 2 \mathrm{H}^{7}\right), 2.01\left(\mathrm{~m}, 2 \mathrm{H}, 2 \mathrm{H}^{12}\right), 3.50(\mathrm{~m}, 3 \mathrm{H}$, $\left.3 \mathrm{H}^{3}\right), 2.27\left(\mathrm{~m}, 2 \mathrm{H}, 2 \mathrm{H}^{4}\right), 5.01\left(\mathrm{dd}, 1 \mathrm{H}, \mathrm{H}^{22}\right), 5.16$ $\left(\mathrm{dd}, 1 \mathrm{H}, \mathrm{H}^{23}\right), 5.34\left(\mathrm{dd}, 1 \mathrm{H}, \mathrm{H}^{6}\right) .{ }^{13} \mathrm{C}$ NMR $(125$ $\left.\mathrm{MHz}, \mathrm{CDCl}_{3}\right): \delta 37.4\left(\mathrm{C}^{1}\right), 28.4\left(\mathrm{C}^{2}\right), 71.9\left(\mathrm{C}^{3}\right)$, $42.5\left(C^{4}\right), 140.9\left(C^{5}\right), 121.9\left(C^{6}\right), 32.0\left(C^{7}\right), 32.1$ $\left(C^{8}\right), 50.3\left(C^{9}\right), 36.7\left(C^{10}\right), 20.0\left(C^{11}\right), 39.4\left(C^{12}\right)$, $46.0\left(C^{13}\right), 56.9\left(C^{14}\right), 23.2\left(C^{15}\right), 26.3\left(C^{16}\right)$, $56.2\left(\mathrm{C}^{17}\right), 12.0\left(\mathrm{C}^{18}\right), 19.2\left(\mathrm{C}^{19}\right), 40.6\left(\mathrm{C}^{20}\right)$, $19.6\left(C^{21}\right), 138.5\left(C^{22}\right), 129.4\left(C^{23}\right), 51.4\left(C^{24}\right)$, $24.5\left(C^{25}\right), 12.3\left(C^{26}\right), 29.3\left(C^{27}\right), 18.9\left(C^{28}\right)$, $21.2\left(\mathrm{C}^{29}\right)$

\section{Compound P-2 (B-Sitosterol)}

White needle crystals; m.p. $136-139{ }^{\circ} \mathrm{C}$; MW 414; IR $\left(\mathrm{cm}^{-1}\right)$ : 3364, 2925, 2834, 1463, 1375, 1051, 1022, 957, 801; EIMS m/z (\% intensity): 414 ([M] $\left.^{+\cdot}, 40.18\right), 396\left(\left[\mathrm{M}-\mathrm{H}_{2} \mathrm{O}\right]^{+}\right.$, 24.76), 381 $\left(\left[\mathrm{M}-\mathrm{H}_{2} \mathrm{O}-\mathrm{CH}_{3}\right]^{+}, \quad\right.$ 18.14), 329 (29.71), 303 (20.05), 273 (11.61), 255 (22.11), 231 (14.86), 213 (20.06), 185 (5.63), 173 (15.89), 159 (25.87), 145 (38.42), 133 (26.78), 119 (31.11), 107 (48.03), 105 (46.22), 95 (45.18), 93 (35.74), 81 (52.19), 57 (60.27), 43 (100), 41 (40.2); ${ }^{1} \mathrm{H}$ NMR (500 MHz, $\mathrm{CDCl}_{3}$ ): $\delta 0.68$ (s, $\left.3 \mathrm{H}, 3 \mathrm{H}^{18}\right), 0.83\left(\mathrm{~d}, 9 \mathrm{H}, 3 \mathrm{H}^{26}, 3 \mathrm{H}^{28}, 3 \mathrm{H}^{29}\right), 0.92$ $\left(\mathrm{s}, 3 \mathrm{H}, 3 \mathrm{H}^{21}\right), 0.95\left(\mathrm{~m}, 1 \mathrm{H}, \mathrm{H}^{9}\right), 1.01(\mathrm{~s}, 3 \mathrm{H}$, $\left.3 \mathrm{H}^{18}\right), 1.09\left(\mathrm{~m}, 1 \mathrm{H}, \mathrm{H}^{15 a}\right), 1.10\left(\mathrm{~m}, 1 \mathrm{H}, \mathrm{H}^{14}\right)$, $1.20\left(\mathrm{~m}, 3 \mathrm{H}, 2 \mathrm{H}^{25}, \mathrm{H}^{17}\right), 1.28\left(\mathrm{~m}, 1 \mathrm{H}, \mathrm{H}^{20}\right), 1.30$ $\left(\mathrm{m}, 1 \mathrm{H}, \mathrm{H}^{1 \mathrm{~b}}\right), 1.50\left(\mathrm{~m}, 6 \mathrm{H}, 2 \mathrm{H}^{2}, 2 \mathrm{H}^{11}, 2 \mathrm{H}^{24}\right), 1.70$ $\left(\mathrm{m}, 6 \mathrm{H}, \mathrm{H}^{16}, \mathrm{H}^{15 \mathrm{~b}}, \mathrm{H}^{8}\right), 1.84\left(\mathrm{~m}, 1 \mathrm{H}, \mathrm{H}^{1 \mathrm{a}}\right), 1.98$ $\left(\mathrm{m}, 2 \mathrm{H}, 2 \mathrm{H}^{7}\right), 2.01\left(\mathrm{~m}, 2 \mathrm{H}, 2 \mathrm{H}^{12}\right), 3.50(\mathrm{~m}, 3 \mathrm{H}$, $\left.3 \mathrm{H}^{3}\right), 2.27\left(\mathrm{~m}, 2 \mathrm{H}, 2 \mathrm{H}^{4}\right), 1.20\left(\mathrm{~m}, 2 \mathrm{H}, 2 \mathrm{H}^{22}\right)$, $1.70\left(\mathrm{~m}, 2 \mathrm{H}, 2 \mathrm{H}^{23}\right), 5.34\left(\mathrm{dd}, 1 \mathrm{H}, \mathrm{H}^{6}\right) ;{ }^{13} \mathrm{C}$ NMR $\left(125 \mathrm{MHz}, \mathrm{CDCl}_{3}\right)$ : $\delta 37.4\left(\mathrm{C}^{1}\right), 28.4\left(\mathrm{C}^{2}\right), 71.9$ $\left(C^{3}\right), 42.5\left(C^{4}\right), 140.9\left(C^{5}\right), 121.9\left(C^{6}\right), 32.0\left(C^{7}\right)$, $32.1\left(C^{8}\right), 50.3\left(C^{9}\right), 36.7\left(C^{10}\right), 20.0\left(C^{11}\right), 39.4$ $\left(C^{12}\right), 46.0\left(C^{13}\right), 56.9\left(C^{14}\right), 23.2\left(C^{15}\right), 26.3$ $\left(C^{16}\right), 56.2\left(C^{17}\right), 12.0\left(C^{18}\right), 19.2\left(C^{19}\right), 40.6$ $\left(\mathrm{C}^{20}\right), 19.6\left(\mathrm{C}^{21}\right), 33.9\left(\mathrm{C}^{22}\right), 28.3\left(\mathrm{C}^{23}\right), 51.4$ $\left(\mathrm{C}^{24}\right), 24.5\left(\mathrm{C}^{25}\right), 12.3\left(\mathrm{C}^{26}\right), 29.3\left(\mathrm{C}^{27}\right), 18.9$ $\left(\mathrm{C}^{28}\right), 21.2\left(\mathrm{C}^{29}\right)$ 
Tabel 1- ${ }^{1} \mathrm{H}$ NMR and ${ }^{13} \mathrm{C}$ NMR spectroscopic data of the isolated compound

\begin{tabular}{|c|c|c|c|c|c|c|}
\hline \multirow{2}{*}{ C } & \multicolumn{3}{|c|}{ Compound 109a (Stigmasterol) } & \multicolumn{3}{|c|}{ Compound 109b (B-sitosterol) } \\
\hline & $\delta \mathrm{H}$ & $\delta C$ & $\delta C^{*}$ & $\delta \mathrm{H}$ & $\delta C$ & $\delta C^{*}$ \\
\hline 1 & $\begin{array}{l}1.84(1 \mathrm{H}, \mathrm{m}) ; \\
1.30(1 \mathrm{H}, \mathrm{m})\end{array}$ & 37.4 & 37.2 & $\begin{array}{l}1.84(1 \mathrm{H}, \mathrm{m}) ; \\
1.30(1 \mathrm{H}, \mathrm{m})\end{array}$ & 37.4 & 37.3 \\
\hline 3 & $3.50(3 \mathrm{H}, \mathrm{m})$ & 71.9 & 70.3 & $3.50(3 \mathrm{H}, \mathrm{m})$ & 71.9 & 71.7 \\
\hline 4 & $2.27(2 \mathrm{H}, \mathrm{m})$ & 42.5 & 42.0 & $2.27(2 \mathrm{H}, \mathrm{m})$ & 42.5 & 42.3 \\
\hline 5 & - & 140.9 & 141.6 & - & 140.9 & 140.8 \\
\hline 8 & $1.70(1 \mathrm{H}, \mathrm{m})$ & 32.1 & 31.8 & $1.70(1 \mathrm{H}, \mathrm{m})$ & 32.1 & 31.9 \\
\hline 9 & $0.92(1 \mathrm{H}, \mathrm{m})$ & 50.3 & 50.1 & $0.92(1 \mathrm{H}, \mathrm{m})$ & 50.3 & 50.2 \\
\hline 10 & - & 36.7 & 36.3 & - & 36.7 & 36.5 \\
\hline 11 & $1.50(2 \mathrm{H}, \mathrm{m})$ & 20.0 & 20.8 & $1.50(2 \mathrm{H}, \mathrm{m})$ & 20.0 & 21.1 \\
\hline 12 & $2.01(2 \mathrm{H}, \mathrm{m})$ & 39.9 & 39.4 & $2.01(2 \mathrm{H}, \mathrm{m})$ & 39.9 & 39.8 \\
\hline 16 & $1.70(2 \mathrm{H}, \mathrm{m})$ & 26.3 & 28.1 & $1.70(2 \mathrm{H}, \mathrm{m})$ & 26.3 & 28.3 \\
\hline 17 & $1.20(1 \mathrm{H}, \mathrm{m})$ & 56.2 & 55.9 & $1.20(1 \mathrm{H}, \mathrm{m})$ & 56.2 & 56.1 \\
\hline 18 & $0.68(3 \mathrm{H}, \mathrm{s})^{\prime}$ & 12.0 & 11.8 & $0.68(3 \mathrm{H}, \mathrm{s})^{\prime}$ & 12.0 & 11.9 \\
\hline 19 & $1.01(3 \mathrm{H}, \mathrm{s})$ & 19.2 & 19.1 & $1.01(3 \mathrm{H}, \mathrm{s})$ & 19.2 & 19.4 \\
\hline 20 & $1.28(1 \mathrm{H}, \mathrm{m})$ & 40.6 & 40.3 & $1.28(1 \mathrm{H}, \mathrm{m})$ & 40.6 & 36.2 \\
\hline 21 & $0.92(3 \mathrm{H}, \mathrm{s})$ & 19.6 & 20.6 & $0.92(3 \mathrm{H}, \mathrm{s})$ & 19.6 & 18.8 \\
\hline 22 & $5.01(1 \mathrm{H}, \mathrm{dd})$ & 138.5 & 137.7 & $1.20(2 \mathrm{H}, \mathrm{m})$ & 33.90 & 33.9 \\
\hline 23 & $5.16(1 \mathrm{H}, \mathrm{dd})$ & 129.4 & 129.3 & $1.7(2 \mathrm{H}, \mathrm{m})$ & 28.30 & 26.1 \\
\hline 24 & $1.50(2 \mathrm{H}, \mathrm{m})$ & 51.4 & 50.6 & $1.50(2 \mathrm{H}, \mathrm{m})$ & 51.4 & 45.9 \\
\hline 25 & $1.20(2 \mathrm{H}, \mathrm{m})$ & 24.5 & 24.7 & $1.2(2 \mathrm{H}, \mathrm{m})$ & 24.5 & 23.1 \\
\hline 26 & $0.83(3 \mathrm{H}, \mathrm{d})$ & 12.3 & 11.9 & $0.83(3 \mathrm{H}, \mathrm{d})$ & 12.3 & 12.3 \\
\hline 27 & $1.90(1 \mathrm{H}, \mathrm{m})$ & 29.3 & 31.50 & $1.90(1 \mathrm{H}, \mathrm{m})$ & 29.3 & 29.2 \\
\hline
\end{tabular}

Note : $\delta C^{*}$ is data base of carbon chemical shift from SDBS AIST Japan

The TLC analysis of petroleum ether extract of bengkoang has been carried out to find out how many compounds are in the extract and their distribution. This step was necessary before doing isolation and determination. Figure 1 displayed the TLC chromatogram of bengkoang extract and fraction containing phytosterol.

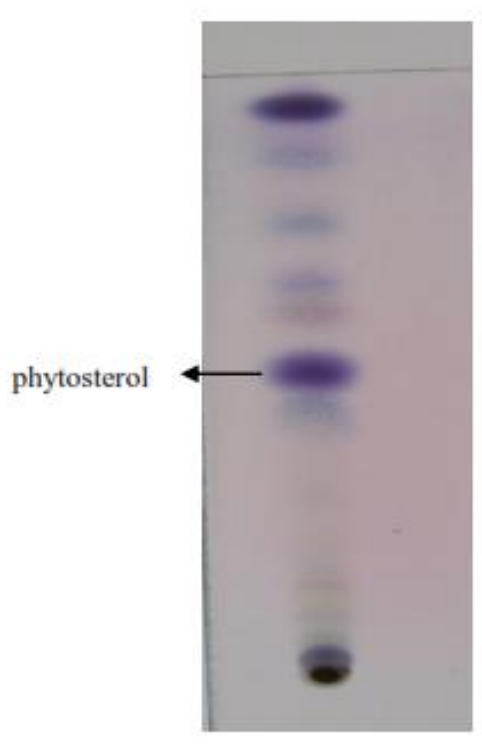

A

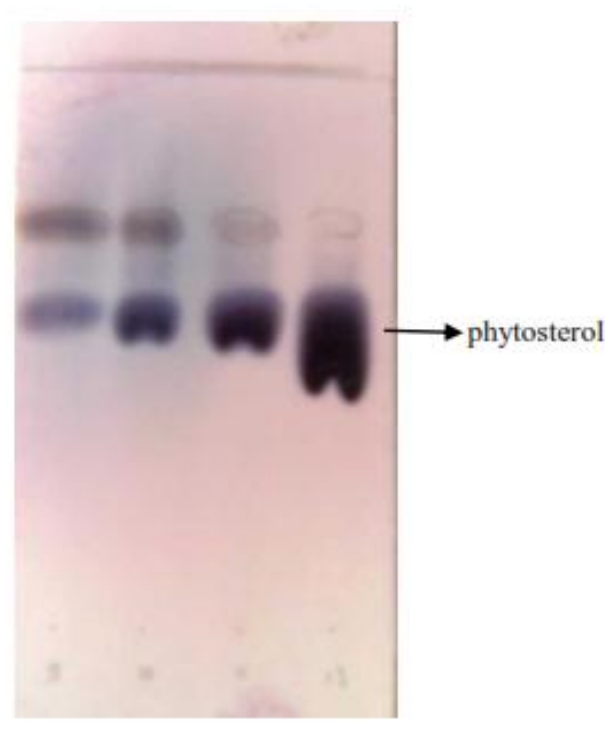

B

Fig.1-The TLC chromatogram of petroleum extract (A) and fraction 8, 9,10,11 containing phytosterols (B). The TLC system consists of silica as stationary phase and a mixture of chloroform-methanol (60:40) as mobile phase and detected by anisaldehyde

The isolated compound from fractions $8,1699 \mathrm{~cm}^{-1}$ indicated the presence of $\mathrm{C}=\mathrm{C}$ or $9,10,11$ of the petroleum ether extract as white $\mathrm{C}=\mathrm{O}$. Additionally the IR spectrum showed needle crystals having a melting point of 136 $139{ }^{\circ} \mathrm{C}$. The IR spectrum showed bands at

$\mathrm{C}=\mathrm{O}$. Additionally the IR spectrum showed
$3364 \mathrm{~cm}^{-1}$ (-OH group), $2925 \mathrm{~cm}^{-1}(-\mathrm{C}-\mathrm{H}$ aliphatic group), $1463 \mathrm{~cm}^{-1}$ (-CH group), 1375 
$\mathrm{cm}^{-1}\left(-\mathrm{CH}\right.$ group) and $1051 \mathrm{~cm}^{-1}(-\mathrm{C}-\mathrm{O}-\mathrm{C}$ group).

An analysis using gas chromatogram has been conducted and the chromatogram can be seen in Figure 2. The chromatogram showed two peaks with retention times of 31.2 and 32.4 min, corresponding to the molecular ion peaks at $\mathrm{m} / \mathrm{z} 412$ and 414 , respectively. They are consistent with the molecular formula $\mathrm{C}_{29} \mathrm{H}_{48} \mathrm{O}$ (e.g. stigmasterol) and $\mathrm{C}_{29} \mathrm{H}_{50} \mathrm{O}$ (e.g. Bsitosterol).

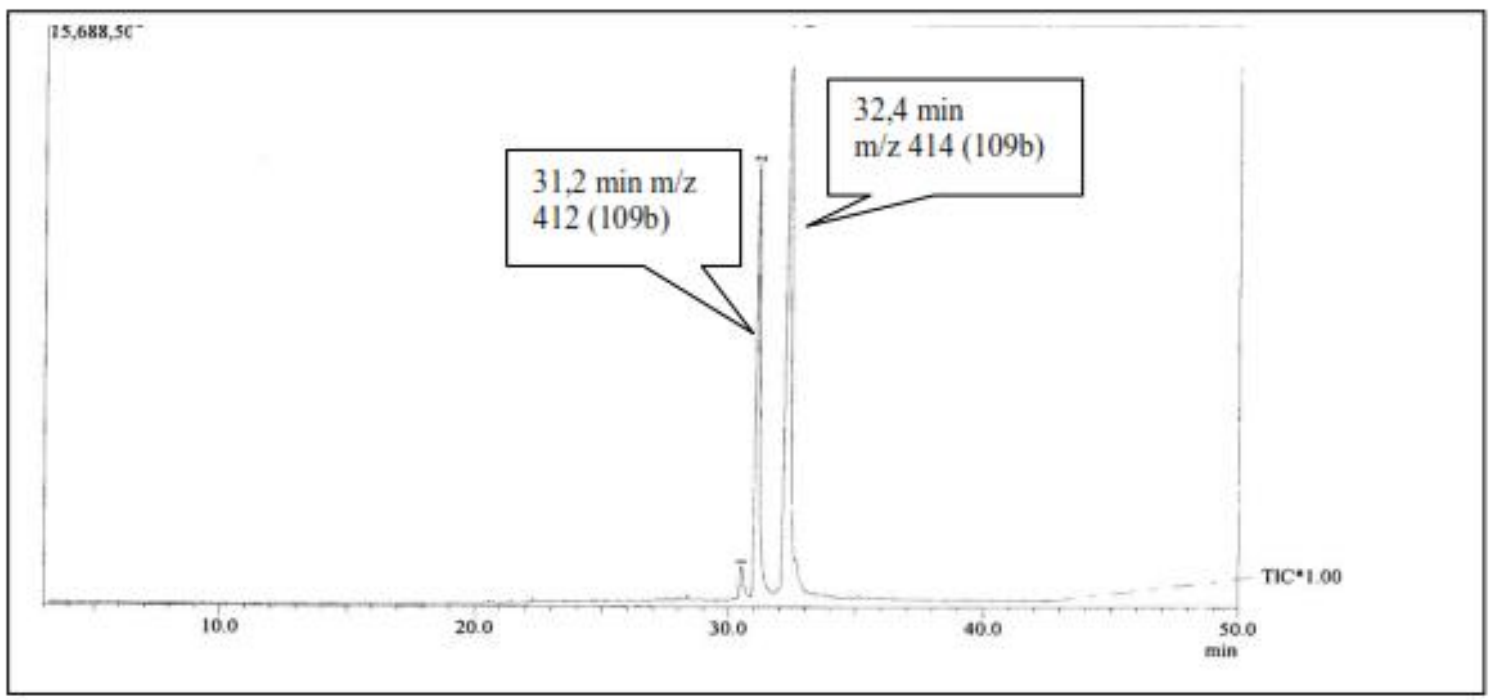

Figure 2. Gas chromatogram Mass Spectroscopy of the sample, the chromatogram showed two peaks with retention times of 31.2 and $32.4 \mathrm{~min}$, corresponding to the molecular ion peaks at $\mathrm{m} / \mathrm{z} 412$ and 414 , respectively.

The hypothesis that the isolated compound was a mixture of a B-sitosterol and stigmasterol supported by the results of NMR spectrum and the fragmentation pattern in MS spectrum. The El-MS spectrum showed the presence of the hydroxyl group was supported by the strong loss of 18 mass units in both $\mathrm{El}$ mass spectrums. The existence of a double bond of C-C was represented in the ${ }^{13} \mathrm{C}-\mathrm{NMR}$ by four downfield signals at $\delta 140.9 \mathrm{ppm}$ (quarternary carbon), $121.9 \mathrm{ppm}(\mathrm{CH}), 129.4$ ppm $(\mathrm{CH})$ and $138.5 \mathrm{ppm}(\mathrm{CH})$. The carbon chemical shift data of $\mathbf{P}-\mathbf{1}$ was similar to $\mathbf{P}-\mathbf{2}$, except $\delta C^{22}$ and $C^{23}$. The carbon chemical shifts of $C^{22}$ from P-1 and P-2 were 33.9 ppm and $138.5 \mathrm{ppm}$, respectively. Meanwhile the carbon chemical shifts of $\mathrm{C}^{23}$ of $\mathbf{P}-\mathbf{1}$ and $\mathbf{P}-\mathbf{2}$ were $28.3 \mathrm{ppm}$ and $129.4 \mathrm{ppm}$, respectively. All the carbon chemical shift data of the ${ }^{13} \mathrm{C}$ NMR spectrum (Table I) were in a close agreement with those of stigmasterol and Bsitosterol in literature reported (Kovganko et al. 2000) and also with the database in SDBS AIST Japan.

The downfield signal in the ${ }^{1} \mathrm{H}-\mathrm{NMR}$ spectrum at $\delta 5.34(1 \mathrm{H}$, dd) was due to an olefinic proton at $C^{6}$ and a methine proton at $C^{3}$ was represented by multiplet signal at $3.50(1 \mathrm{H}$, $\mathrm{m})$. The presence of a pair of doublets at $\delta 5.01$ and $\delta 5.16$ was due to the $\mathrm{sp}^{2}$ methine protons at $\mathrm{C}^{22}$ and $\mathrm{C}^{23}$ in molecule $\mathbf{P}-\mathbf{1}$. The existence of six methyl signals was also noted at $\delta 0.68$ $\left(\mathrm{H}^{3}-\mathrm{C}^{18}\right), 1.01\left(\mathrm{H}^{3}-\mathrm{C}^{19}\right), 0.92\left(\mathrm{H}^{3}-\mathrm{C}^{21}\right), 0.83\left(\mathrm{H}^{3}-\right.$ $\left.\mathrm{C}^{28}\right), 0.83\left(\mathrm{H}^{3}-\mathrm{C}^{29}\right)$.

The COSY correlations between $\mathrm{H}^{6}$ and $\mathrm{H}^{7} ; \mathrm{H}^{22}$ and $\mathrm{H}^{23} ; \mathrm{H}^{3}$ and $\mathrm{H}^{4} ; \mathrm{H}^{11}$ and $\mathrm{H}^{12} ; \mathrm{H}^{1}$ and $\mathrm{H}^{2} ; \mathrm{H}^{2}$ and $\mathrm{H}^{3} ; \mathrm{H}^{20}$ and $\mathrm{H}^{22}$ supported the stigmasterol and B-sitosterol (Fig. 3). Some of the ${ }^{1} \mathrm{H}^{13} \mathrm{C}$-long range correlations (Fig. 4) observed in the HMBC diagram confirmed that the structures of $\mathbf{P}-\mathbf{1}$ and $\mathbf{P}-\mathbf{2}$ were stigmasterol and B-sitosterol.

The mass fragmentation pattern of the $\mathbf{P}$ 1 is displayed in Figure 5. The molecular ion of P-1 was observed at $\mathrm{m} / \mathrm{z} 412$. The loss of water from P-1 was indicated by the presence of a fragment ion at $\mathrm{m} / \mathrm{z} 394$. The subsequent fragment at $\mathrm{m} / \mathrm{z} 379$ might be due to the loss of a methyl group. The signal at $\mathrm{m} / \mathrm{z} 271$ was the characteristic of the stigmasterol fragmentation due to the loss of side chain followed by the loss of two hydrogen atoms. 


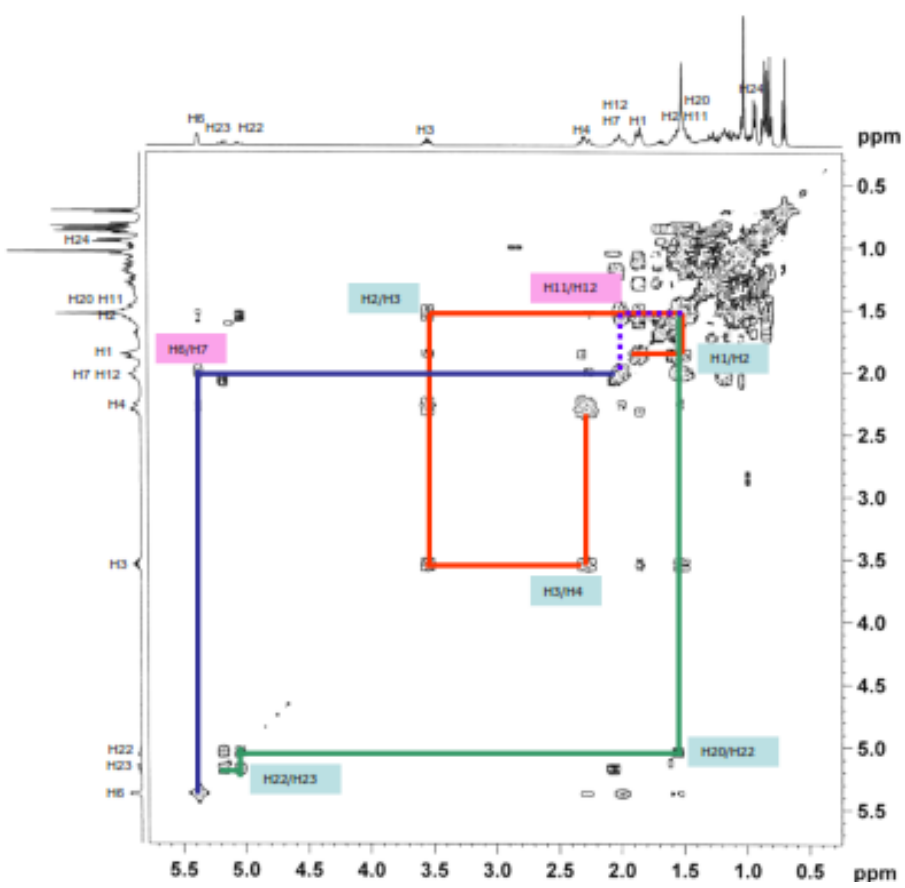

Fig. 3-COSY diagram of the mixture of the isolated compound

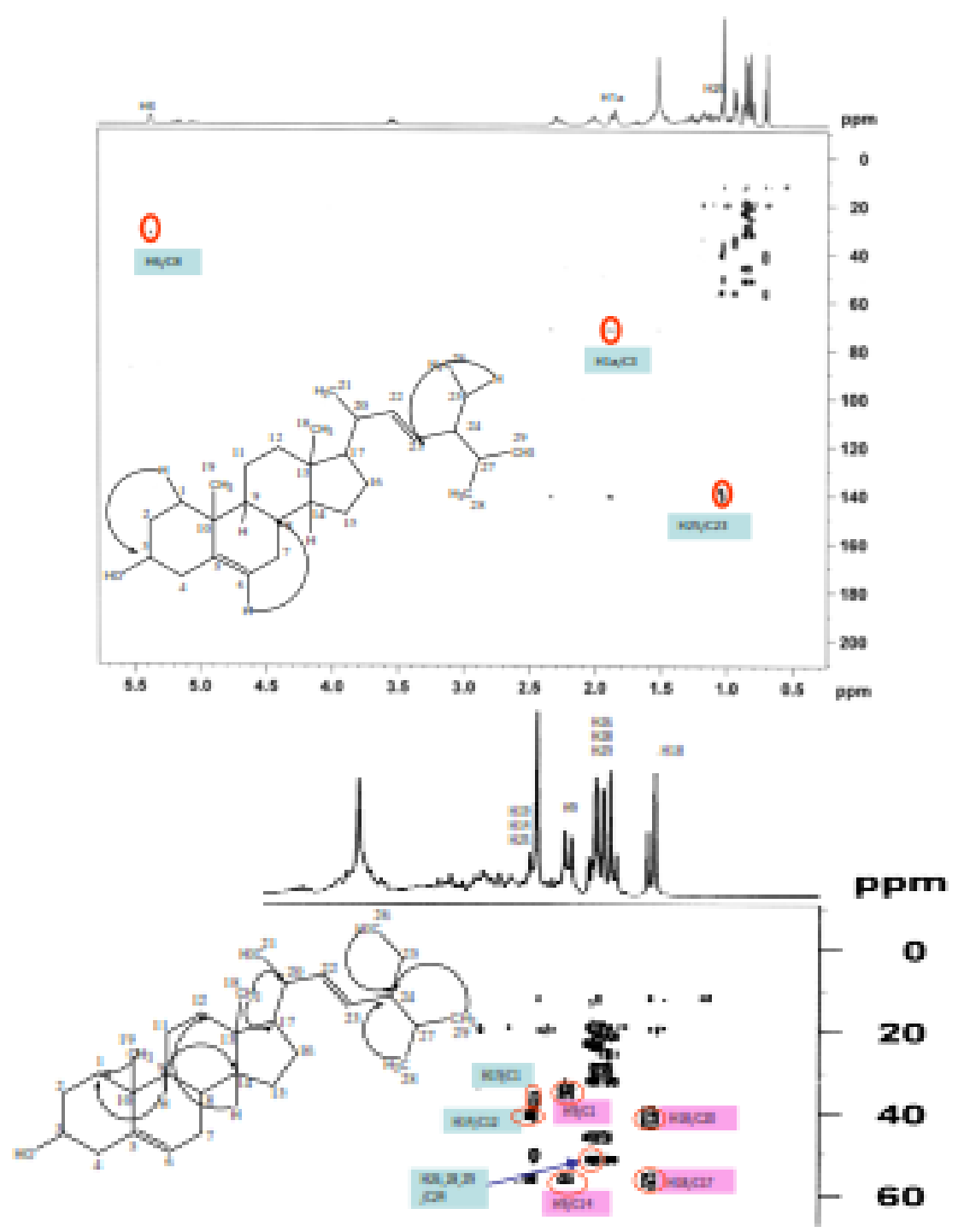

Fig. 4-MBC diagram of the mixture of compounds 109a and 109b 


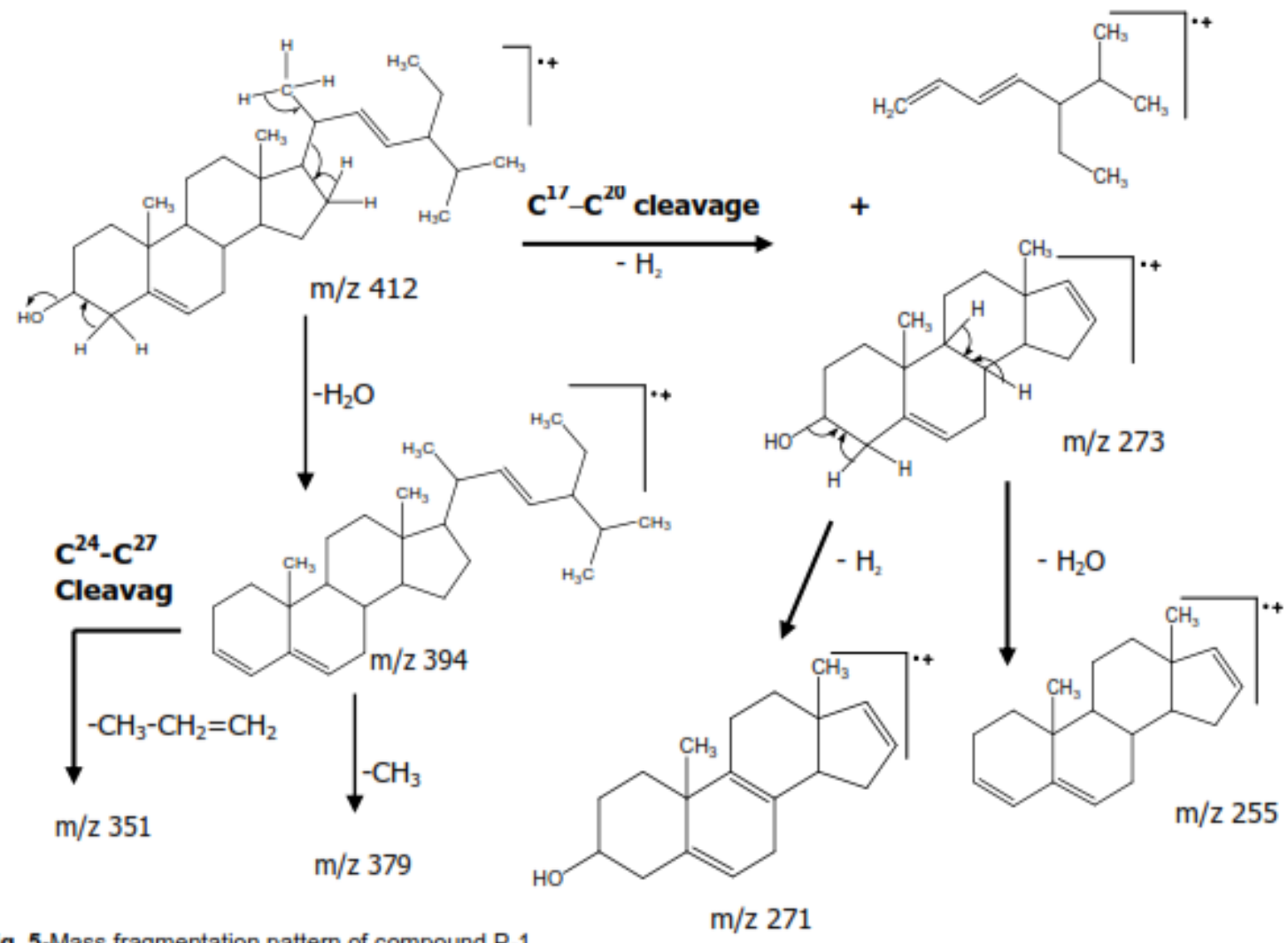

Fig. 5-Mass fragmentation pattern of compound P-1

$\mathrm{m} / \mathrm{z} 271$

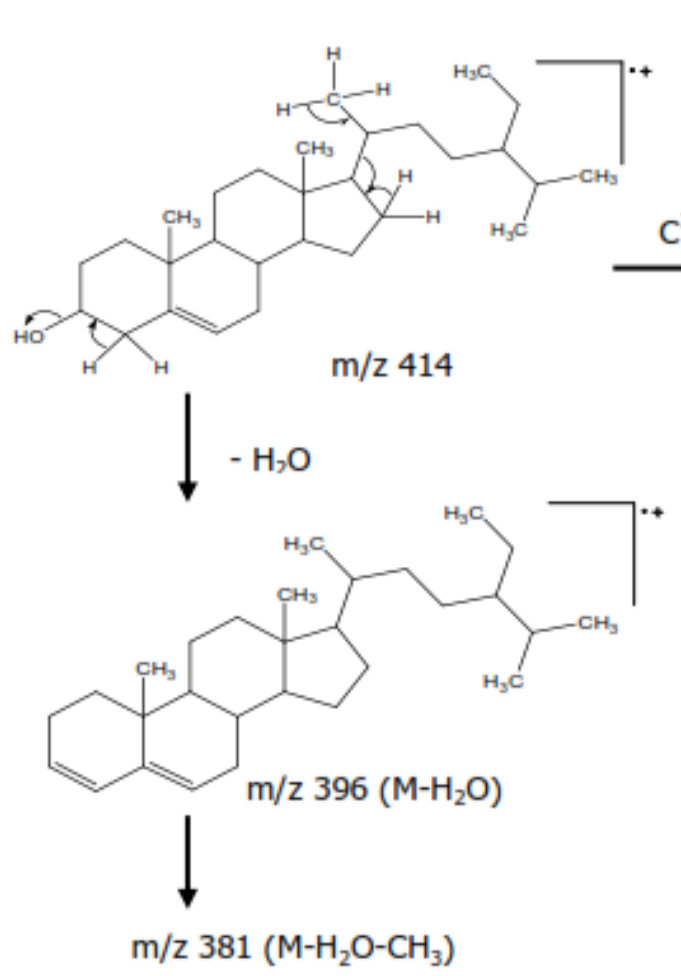<smiles>C=CCCC(CC)C(C)C</smiles><smiles>[R16][R16]</smiles><smiles>CCCO</smiles><smiles>CC12CCC=CC1=CCC1C2CCC2(C)C1CC=CC2(C)C</smiles>

$\mathrm{m} / \mathrm{z} 255$

Fig. 6- Mass fragmentation pattern of compound P-2 
The mass fragmentation pattern above was in accordance with previously paper. Chaves et al. (2004) found in GC/MS the fragments with $\mathrm{m} / \mathrm{z}$ value of $412\left(\mathrm{M}^{+}\right), 271$ and 273 . Based on the above fragmentation, this substance $\mathbf{P}-\mathbf{1}$ was identified as stigmasterol.

The Figure 6 displayed a mass fragmentation pattern of P-2 having a molecular ion $\mathrm{m} / \mathrm{z} 414$. The fragment ions at $\mathrm{m} / \mathrm{z} 396$ and 381 were due to the loss of water and followed by a methyl group from the molecular ion. The characteristic observed in the mass spectrum of $\mathbf{P}$ 2 was the presence of a fragment ion peak at $\mathrm{m} / \mathrm{z}$ 273. This signal was in a close agreement with the loss of side chain caused by the fission of $\mathrm{C}^{17}-\mathrm{C}^{20}$ bond. This was further fragmented producing water. From this process, the signal at $\mathrm{m} / \mathrm{z} 255$ was observed.

The fragmentation pattern above is in accordance to Zhang et. al. (2005): B-sitosterol in acid solution produces positive signals at $\mathrm{m} / \mathrm{z}$ 382 and 397 with intensities 52 and 100 , respectively. The signal at $\mathrm{m} / \mathrm{z} 397$ was assigned to $\left(\boldsymbol{M}+\boldsymbol{H}^{+}-\boldsymbol{H}_{2} \mathrm{O}\right)$ and the signal at $\mathrm{m} / \mathrm{z} 382$ to $\left(\boldsymbol{M}+\boldsymbol{H}^{+}\right.$ $-\mathrm{H}_{2} \mathrm{O}-\mathrm{CH}_{3}$ ). In addition, Berezin et al. (2004) and Huang et al. (2007) have investigated the fragmentation of $B$-sitosterol and stigmasetrol using HPLC-MS equipped with APCI. The result showed that B-sitosterol and stigmasterol were protonated by a reactive species in the plasma of ion source. B-Sitosterol had an exact mass of 414.39, which became 397.38 after protonation and loss of water. While stigmasetrol had an exact mass of 412.41 which became 395.4 after protonation and loss of water.

All these spectroscopy data proved the structure of the substance P-1 as stigmasterol and P-2 as B-sitosterol. Based on the gas chromatogram at Figure 2, the concentration ratio of stigmasterol and B-sitosterol from this fraction was $35: 65$.

This research proved that the total phytosterol content in petroleum ether extract of bengkoang was relatively high $(2,76 \%)$ or about $0.02 \%$ of dry weight bengkoang. Therefore, bengkoang can be used as a good source of phytosterol and potentially used as nutritional supplement of cholesterol replacement.

\section{CONCLUSSION}

Bengkoang contained a relatively high of phytosterols consisted of two major compounds, namely B-sitosterol and stigmasterol. Therefore, bengkoang can be further exploited not only as cosmetics material, but also as nutritional supplement especially for cholesterol replacement.

\section{ACKNOWLEDGMENT}

We are grateful to the Germany Academic Exchange Service (DAAD) for financial support.

\section{REFERENCES}

Awad, A.B., Chen, Y.C., Fink, C.S., Hennessey, T., 1996, $\beta$-Sitosterol inhibits HT-29 human colon cancer cell growth and alters membrane lipids, Anticancer Res, 16, 2797-2804.

Benveniste P, 1986, Sterol biosynthesis, Annu Rev Plant Physiol, 37, 275-308

Benveniste P, 2004, Biosynthesis and accumulation of sterols, Annu Rev Plant Bio, 55, 429-457

Benveniste, P., Schaller, H., Bouvier-Nave, P., 2005, Cellular sterol ester synthesis in plants is performed by an enzyme (phospholipid: sterol acyltransferase) different from the yeast and mammalian acyl-CoA: sterol acyltransferases. J Biol Chem 280: 34626-34634

Berezin, M.Y., Dzenitis, J.M., Hughes, B.M., Ho, S.V., 2001, Separation of sterols using zeolites, Phys. Chem., 3, 2184-2189

Demel, R.A. and De Kruyff, B. 1976, The function of sterols in membranes, Biochim. Biophys. Acta, 457, $109-132$

Dewick, P.M., 2002, Medicinal Natural Products: a biosynthethic approach, $2^{\text {nd }}$ Ed., John Wiley and Sons Ltd, 247-272 
Dickson, R.A., Houghton, P.J., Hylands, P.J., 2007, Antibacterial and antioxidant cassane diterpenoids from Caesalpinia benthamiana, Phytochem., 68, , 1436-1441

Downie, A., Fink, S.C., Awad, A.B., 1999, Effect of phytosterols on MDAMB-231 human breast cancer cell growth, FASEB J., 113, A333 [abs.].

Gomes, A., Saha, A., Chatterjee, I., Chakravarty, A.K., 2007, Viper and cobra venom neutralization by Bsitosterol and stigmasterol isolated from the root extract of Pluchea indica Less. (Asteraceae), Phytomedicine, 14, , 637-643

Moon, D-O., Lee, K-J., Choi, Y.H., Kim, G-Y., 2007, B-sitosterol-induced-apoptosis is mediated by the activation of ERK and the downregulation of Akt in MCA-102 murine fibrosarcoma cells, Internatl. Immunopharmacol., 7, 1044-1053

Parra-Delgado, H., Ruiz, G.G., Camacho, A.N., Martinez-Vazquez, M.M., 2004, Anti-inflamatory activity of some extracts and isolates from Leonotis nepetaefolia on TPA-induced edema model, Rev. Soc. Quim. Mex., 48, , 293-295

Schuler I., Milon, A., Nakatani, Y., Ourisson, G., Albrecht, A., Benveniste, P., Hartman, M., 1991, Differential effects of plant sterols on water permeability and on acyl chain ordering of soybean phospatidylcholine bilayers, Proc. Natl. Acad. Sci. USA, 88, 6926-6930

von Holtz, R.L., Fink, C.S., Awad, .A.B., 1998, $\beta$-Sitosterol activates the sphingomyelin cycle and induces apoptosis in LNCaP human prostate cancer cells, Nutr. Cancer, 32, 8-12.

Zhang, X., Julien-David, D., Miesch, M., Geoffroy, P., Raul, F., Roussi, S., Aoud'e-Werner, D., Marchioni,. E., 2005, Identification and quantitative analysis of sitosterol oxides in vegetable oils by capillary gas chromatography-mass spectrometry, Steroids, 70, 896-906 